\title{
Effect of the Extract and Constituents From Hancornia speciosa Fruits in Osteoclasts
}

\section{(ㄷ) (i) (우)}

\author{
Authors \\ Micena Roberta Miranda Alves e Silva ${ }^{{ }^{*}}$, Cinthia Mara da Fonseca Pacheco ${ }^{2}$, Mila Fernandes Moreira Madeira ${ }^{3}$, \\ Adriana Machado Saraiva ${ }^{4}$, Elisângela Alves de Freitas ${ }^{5}$, Thalita Marcolan Valverde 6 , José Hugo de Sousa Gomes ${ }^{7}$, Rodrigo \\ Maia de Pádua7, Gregory Thomas Kitten¹, Sandra Y.Fukada Alves ${ }^{8}$, Fernão Castro Braga ${ }^{7}$, Tarcília Aparecida da Silva ${ }^{4}$
}

\section{Affiliations}

1 Department of Morphology, Institute of Biological Sciences, Universidade Federal de Minas Gerais, Belo Horizonte, MG, Brazil

2 Dental School, Centro Universitário Newton Paiva, Belo Horizonte, MG, Brazil

3 Department of Microbiology, Institute of Biological Sciences, Universidade Federal de Minas Gerais, Belo Horizonte, MG, Brazil

4 Department of Oral Surgery and Oral Pathology, Faculty of Dentistry, Universidade Federal de Minas Gerais, Belo Horizonte, MG, Brazil

5 Universidade Federal de Lavras, Lavras, MG, Brazil

6 Department of Biochemistry and Immunology, Institute of Biological Sciences, Universidade Federal de Minas Gerais, Belo Horizonte, MG, Brazil

7 Department of Pharmaceutical Products, Faculty of Pharmacy, Universidade Federal de Minas Gerais, Belo Horizonte, MG, Brazil

8 Department of Pharmacological Science, Faculty of Pharmacy, University of São Paulo, São Paulo, SP, Brazil

Key words

Hancornia speciosa, Apocynaceae, cell culture, osteoclasts, bone resorption

$\begin{array}{ll}\text { received } & 14.08 .2018 \\ \text { revised } & 02.12 .2018 \\ \text { accepted } & 06.12 .2018\end{array}$

\section{Bibliography}

DOI https://doi.org/10.1055/a-0829-0454

Planta Med Int Open 2019; 6: e7-e14

(c) Georg Thieme Verlag KG Stuttgart · New York

ISSN 2509-9264
Correspondence

Micena Roberta Miranda Alves e Silva, PhD

Avenida Antônio Carlos 6627

Belo Horizonte, MG

CEP: 31270-901

Brazil

Phone: + 5531340930 03,

micenarm@gmail.com

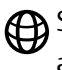
Supporting Information for this article is available online at http://www.thieme-connect.de/products.

\begin{abstract}
Hancornia speciosa is a medicinal species traditionally used in Brazilian folk medicine to treat a variety of conditions. Compounds isolated from the leaves, bark, and trunk of this plant have shown therapeutic properties, but only recently have the fruits of $H$. speciosa been explored for potential pharmacological applications. The present study investigated the effects of an ethanolic extract from the fruits, fractions, and compounds thereof in bone resorbing cells. Primary osteoclast cultures from bone marrow cells and osteoclasts derived from a monocyte/macrophage cell line, RAW 264.7, were incubated with different concentrations of the ethanolic extract, ethyl acetate fraction, water fraction, quinic acid, and L-(+ )-bornesitol. In RAW 264.7 cell cultures, quinic acid significantly reduced osteoclast formation. In bone marrow cell-derived osteoclasts, the ethyl acetate fraction induced a decrease in the number of osteoclasts, promoting a remarkable reduction in the mean area of those cells and in their resorption activity. The compounds quinic acid and bornesitol also affected bone marrow cell-derived osteoclasts. In both cell cultures, the substances tested did not affect cell viability/proliferation. In conclusion, components extracted from $H$. speciosa fruit affected the cells responsible for bone resorption, making them promising tools for interference in osteoclastogenesis.
\end{abstract}

* These authors contributed equally to the work presented in this paper. 


$\begin{array}{ll}\text { ABBREVIATIONS } \\ \text { BMC } & \text { bone marrow cell } \\ \text { EA } & \text { ethyl acetate fraction } \\ \text { EEF } & \text { ethanolic extract } \\ \text { ESI } & \text { electrospray ionization } \\ \text { HILIC } & \text { hydrophilic interaction liquid chromatography } \\ \text { M-CSF } & \text { macrophage colony-stimulating factor } \\ \alpha-M E M & \text { minimum essential medium alpha } \\ \text { MRM } & \text { multiple reaction monitoring } \\ \text { RANKL } & \text { receptor activator of nuclear factor kappa-B ligand } \\ \text { Rt } & \text { retention time } \\ \text { TRAP+ } & \text { tartrate-resistant acid phosphatase } \\ \text { UPLC } & \text { ultra-performance liquid chromatography }\end{array}$

\section{Introduction}

Hancornia speciosa Gomez (Apocynaceae) is an arborous species, vulgarly known as mangabeira in Brazil [1]. Its fruits, called mang$a b a$, are extensively consumed by the Brazilian population, either in natura or in culinary preparations [2], and it is considered an important source of vitamins $C$ and $E$, along with minerals such as calcium and zinc [3].

$H$. speciosa is a medicinal species traditionally used to treat a plethora of conditions, including skin diseases, tuberculosis, hypertension, and gastrointestinal problems [4, 5]. Previously, our research group has demonstrated the chemopreventive [6], antihypertensive [7], antidiabetic [8], and wound healing [9] properties of the species.

To date, only a few studies have investigated the potential therapeutic properties of $\mathrm{H}$. speciosa fruits. A recent publication showed that rutin and chlorogenic acid, isolated from the aqueous extract of the fruits, were able to decrease edema and cell migration in different models of inflammation, and also reduce the levels of proinflammatory cytokines such as IL-1 $1 \beta$, IL-6, IL-12, and TNF- $\alpha[10]$. Another study showed that mangaba pulp has a potential antimutagenic effect [11].

Bone remodeling is a physiological process that involves synthesis and resorption of bone, responsible for maintaining its structure and function during adult life. Osteoclasts are pivotal cells in this process due to promoting bone resorption [12], and inflammatory mediators have an important role in the differentiation and activation of these cells [13]. Since mangaba fruits have shown anti-inflammatory properties [10], we herein investigated the effects of the fruit in bone resorbing cells. The fruits extract along with some fractions and compounds thereof had their activity tested in primary osteoclasts cultures from BMCs and also in osteoclasts derived from a monocyte/macrophage cell line, RAW 264.7.

\section{Results and Discussion}

The chemical composition of EEF and EA was investigated by UPLCESI-MS in the negative mode of ionization ( $\mathbf{F i g . ~ 1 a , ~ b ) . ~ W e ~ i n i t i a l - ~}$ ly employed an ODS (octadecylsilane) column for separation, but several compounds eluted in the dead time (data not shown). Therefore, the analyses were performed on an HILIC column, given that it affords longer Rts for polar compounds, thus enabling their elution after the dead time. HILIC columns can operate in the normal phase and separate polar compounds based on 3 possible mechanisms: a) analyte partitioning between the mobile and stationary phases, b) analyte adsorption onto the adsorbent surface, and c) adsorption of the organic mobile phase onto the adsorbent surface and analyte partitioning onto this thin adsorbed layer [14]. Based on these probable mechanisms, it was possible to separate and identify some polar constituents found in the extract and fractions from $H$. speciosa fruits.

The presence of quinic acid ( $\mathrm{Rt}=0.51 \mathrm{~min}$; $\boldsymbol{\text { Fig. }} \mathbf{1 c}$ ), (iso)chlorogenic acid ( $R t=1.93 \mathrm{~min}$; $\mathbf{F i g} . \mathbf{1 d})$, and rutin ( $R t=2.74 \mathrm{~min}$; - Fig. 1e) at EEF was evidenced by the deprotonated molecules, respectively, at $\mathrm{m} / \mathrm{z} 191.16[\mathrm{M}-\mathrm{H}]^{-}, \mathrm{m} / \mathrm{z} 353.22[\mathrm{M}-\mathrm{H}]^{-}$, and $\mathrm{m} / \mathrm{z}$ $609.37[\mathrm{M}-\mathrm{H}]^{-}$, which are not present in the water fraction ( $\mathbf{F i g . 1 S}$, Supporting Information). Bornesitol ( $\mathrm{Rt}=2.98 \mathrm{~min}$ ) was identified employing distinct chromatographic and spectroscopic conditions, specifically MRM. The transition selected to MRM analysis corresponds to the loss of methanol from bornesitol, resulting in the fragment detected at $\mathrm{m} / \mathrm{z} 161.01\left[\mathrm{M}-\mathrm{CH}_{3} \mathrm{OH}-\mathrm{H}\right]^{-}$, as described by us in a previous publication [15]. The MRM approach based on this transition allows the unambiguous identification of bornesitol, even in complex matrices. The analysis of EA by UPLC-ESI-MS led to the identification of the same compounds found in EEF.

Our next goal was to investigate the effect of $H$. speciosa fruits and their constituents in cells related to bone resorption. For this, we firstly exposed osteoclasts differentiated from a monocyte/macrophage cell line (RAW 264.7) to different concentrations of EEF and fractions thereof. As far as cell viability/proliferation was concerned, neither EEF nor its fractions had an impact on the cells. Cell proliferation and viability are important indicators for evaluating biological effects and, primarily, pharmacological safety during drug development [16].

To evaluate the effect of the compounds in osteoclast differentiation, TRAP + cells were counted after 7 days of culture. The results showed that the highest concentration $(90 \mu \mathrm{g} / \mathrm{mL})$ of EEF showed a trend to reduce the number of TRAP + cells ( $\mathbf{F i g . ~} \mathbf{2 a}$ ). Similarly, the EA and water fractions also showed a trend to decrease the osteoclast count ( $\vee$ Fig. $\mathbf{2 b}, \mathbf{c}$ ), although none of the results were statistically significant. On the other hand, the lowest dose of quinic acid significantly reduced osteoclast formation ( $\triangleright$ Fig. 2d), while bornesitol had no effect on the osteoclast number ( Fig. 2e).

Many plant-derived substances have been shown to exhibit potential effects in cells related to bone metabolism, as demonstrated by in vitro and in vivo studies. Some compounds have indeed been described to inhibit osteoclast resorption activity. In this regard, a water extract from Malva verticillata $\mathrm{L}$. (Malvaceae) seeds inhibited osteoclastogenesis stimulated by RANKL in bone marrow macrophages [17]. Moreover, a water extract from Acer tegmentosum Maxim (Sapindaceae) stems demonstrated a protective effect on bone destruction by inhibiting osteoclast differentiation and function [18]. Also, caffeic, chlorogenic, and isochlorogenic acids extracted from Simon sweet potato suppressed severe bone de- 

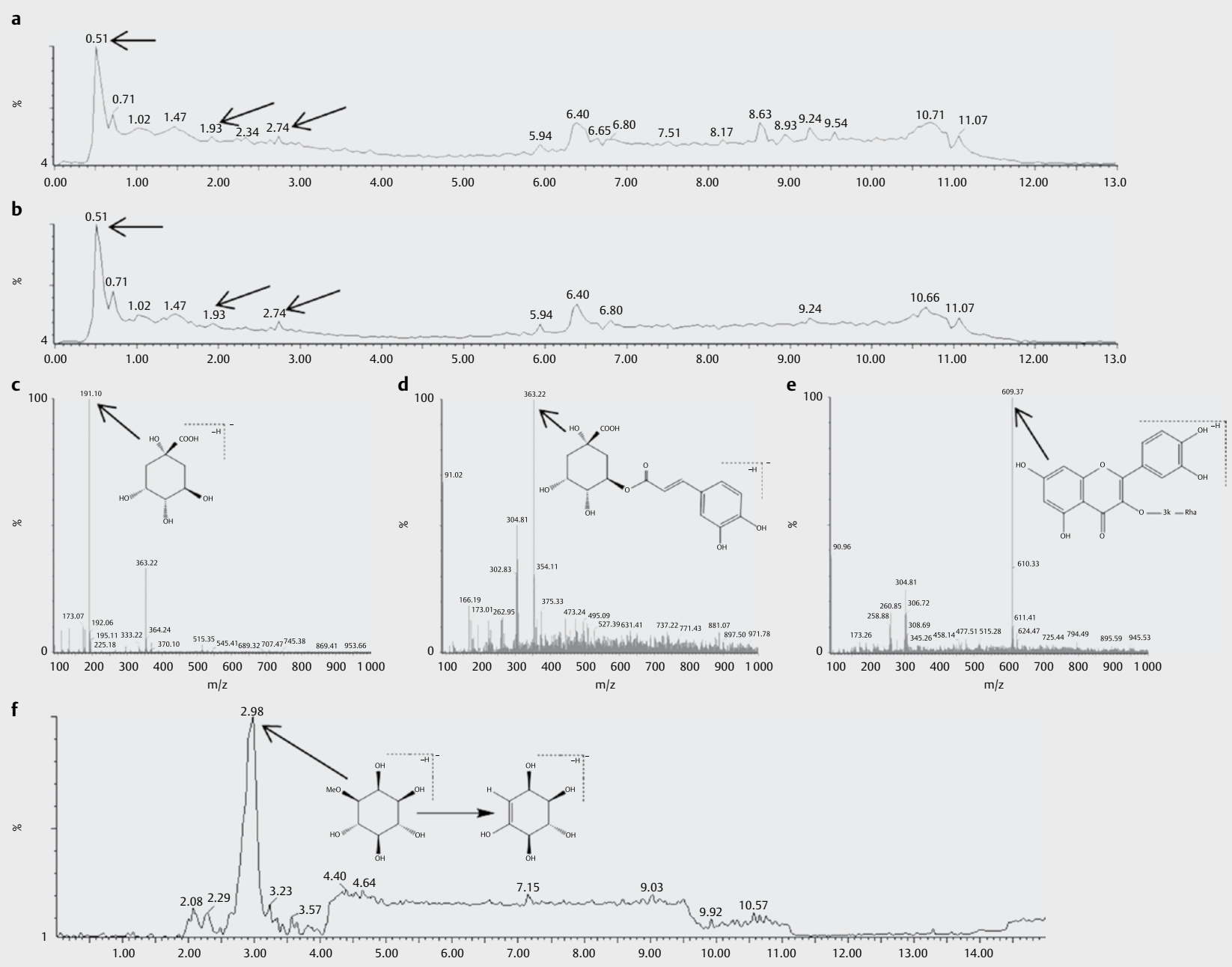

- Fig. 1 Identification of the chemical constituents of EEF $\mathbf{a}$ and EA $\mathbf{b}$ by UHPLC-ESI-MS operating in the negative ionization mode. The presence of quinic acid ( $\mathrm{Rt}=0.51 \mathrm{~min}$ ), (iso)chlorogenic acid $(\mathrm{Rt}=1.93 \mathrm{~min}$ ), and rutin ( $\mathrm{Rt}=2.74 \mathrm{~min}$ ) was evidenced by the deprotonated molecules observed, respectively, at $\mathrm{m} / \mathrm{z}$ 191.16 Da c, $\mathrm{m} / \mathrm{z}$ 353.22 Da d, and $\mathrm{m} / \mathrm{z}$ 609.37 Da e. The identification of bornesitol (Rt=2.98 min) was achieved by the chromatogram registered in the MRM mode $\mathbf{f}$, corresponding to the transition $\mathrm{m} / \mathrm{z} 193 \rightarrow 161 \mathrm{Da}$.

struction mediated by abundant osteoclasts in a model of adjuvantinduced arthritis in rats [19].

Osteoclasts are the main cells related to bone resorption, and most adult skeletal diseases are due to increased osteoclastic activity, leading to an imbalance in bone remodeling favoring resorption [20]. Thus, searching for substances that interfere with osteoclastic activity is of great interest, especially for those with a high pharmacological effect but minimal side effects. In this sense, substances derived from commonly consumed fruits, such as those isolated in the present study, can be promising pharmacological tools to treat bone destructive-related diseases. As far as we know, no constituent from $H$. speciosa fruits has been reported to date to affect the major bone resorbing cells.

Besides the effects in bone resorbing cells, plant compounds such as flavonoids and phenolic acids have been shown to favor osteoblastic bone formation [21]. Consistently, the latex extracted from the $H$. speciosa trunk has been previously reported to stimulate bone formation [22] and the effect was credited to its constit- uents, chlorogenic acid and naringenin-7-O-glucoside, although the isolated compounds were not tested by the authors. In future studies, we intend to investigate the effect of $H$. speciosa fruit derivatives in bone forming cells.

Although only one of the compounds isolated from EEF had a significant effect in reducing osteoclast counting in RAW 264.7 cell cultures, we sought to verify the effect of the same previously tested samples in the differentiation of osteoclasts from BMCs. Cell lines are genetically manipulated and this may alter their phenotype, native functions, and their responsiveness to stimuli [23]. In this sense, the use of primary cells could provide results not observed with the cell line RAW 264.7. In BMC-derived osteoclasts, in addition to TRAP + cells counting, we also measured the area of these cells and their resorption activity. The results showed that EEF did not significantly affect either the mean number ( $>$ Fig. 3a) or the mean total area of the TRAP + cells ( $\mathbf{F i g . ~} \mathbf{3 b}$ ), although a trend to decrease the mean area could be observed with the highest tested concentration of EEF ( $\vee$ Fig. $\mathbf{3 c}$, d). To verify the func- 

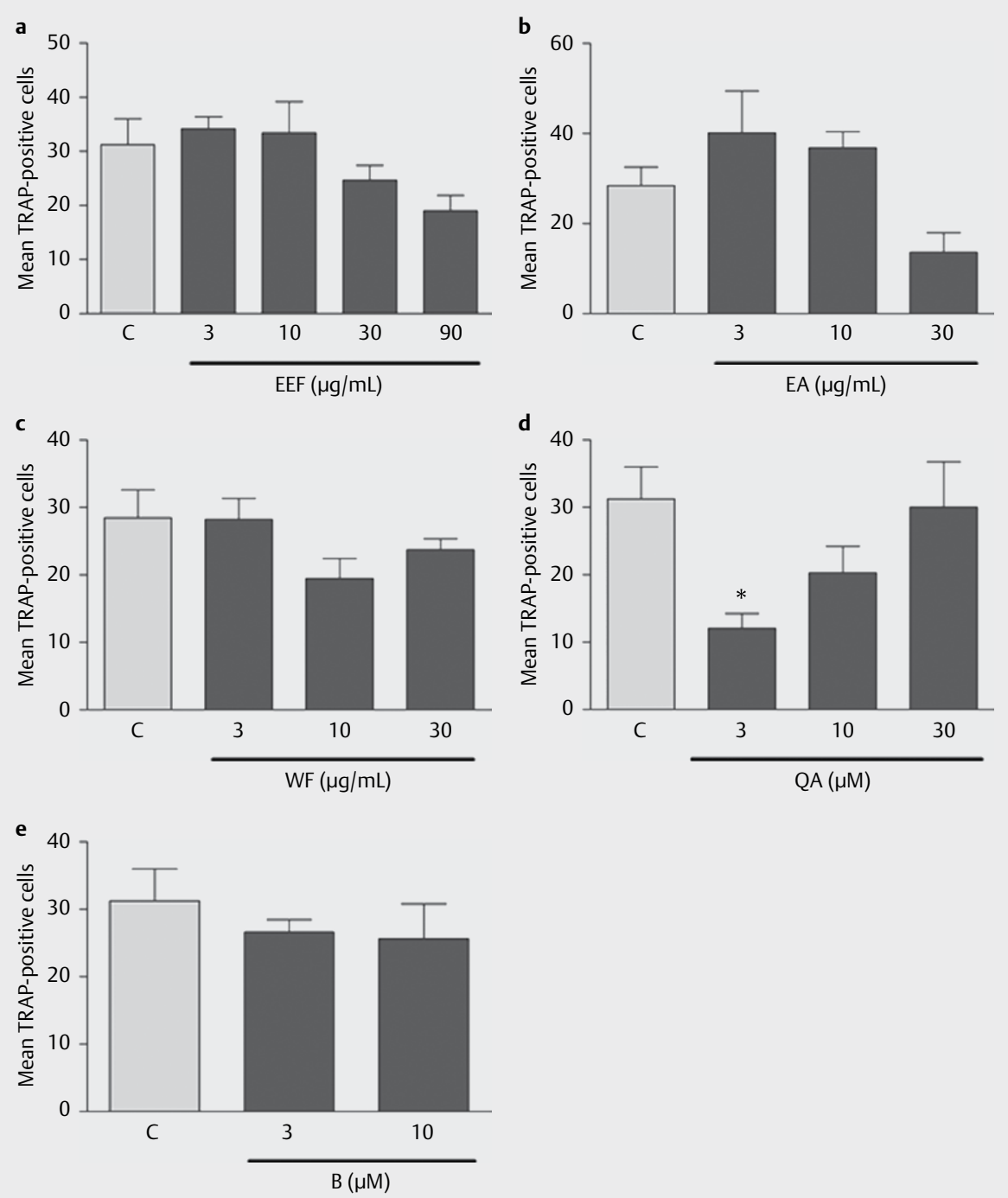

- Fig. 2 Effect of $H$. speciosa ethanolic extract (EEF), ethyl acetate fraction (EA), water fraction (WF) and constituents quinic acid (QA) and bornesitol (B) on RANKL - induced osteoclast differentiation in RAW 264.7 cells. PBS was used as control - C for EEF, QA and B, while DMSO was used as control for WF and EA. ${ }^{*} \mathrm{p}<0.05$ indicates statistically significant differences from the control group (PBS or DMSO).

tional resorption activity of differentiated cells, the detection of resorption pits was performed. The results showed no effect of the extract in decrease pit formation ( $>$ Fig. 3e, f). However, when the cells were exposed to the EA, a decrease in the number of TRAP + cells was achieved with the lowest assayed concentration ( $\vee$ Fig. 4a). Furthermore, the highest concentration of EA caused a remarkable decrease in the mean area of TRAP + cells ( $\triangleright$ Fig. $\mathbf{4 b - d}$ ) and resorption pit formation ( $\vee$ Fig. 4 e, f), despite an increase in the mean number of TRAP + cells ( $>$ Fig. $4 \mathbf{4 a}$ ). Other plant extracts have also been reported to elicit a decrease in the resorptive activity of osteoclasts, without interfering with their number $[17,18]$. Herein, we demonstrate for the first time that a fraction derived from EEF of $H$. speciosa fruits was able to decrease osteoclast activity.

Only recently the fruits of $H$. speciosa have been investigated for their potential pharmacological activity. Rutin and chlorogenic acid were the bioactive constituents isolated from an aqueous extract of the fruits that showed a role in controlling inflammatory events
[10]. The fruit pulp, in which phenolic compounds such as gallic acid, catechin, chlorogenic acid, vanillic acid, o-coumaric acid, rosmarinic acid, and rutin were identified, has shown an antimutagenic effect [11].

Regarding quinic acid and bornesitol, two cyclitols found in EA from $H$. speciosa fruits, each one had a different effect on BMC-derived osteoclasts ( $\triangleright$ Figs. $\mathbf{2 S}$ and $\$ \mathbf{3 S}$, Supporting Information). Bornesitol decreased the number of TRAP + cells at the highest concentration tested $(10 \mu \mathrm{M})$, despite an increase in resorption pits, but it decreased the mean area of those cells at the lower assayed concentration $(3 \mu \mathrm{M})$. Quinic acid had no effect in the total number of TRAP + cells and their areas, although an increase in resorption pits could be observed.

Osteoclast bone resorption is a multistep process that initiates with the differentiation of monocyte/macrophage precursors cells at or near the bone surface and their further fusion to one another to form a multinucleated cell, which attach to bone and starts to 

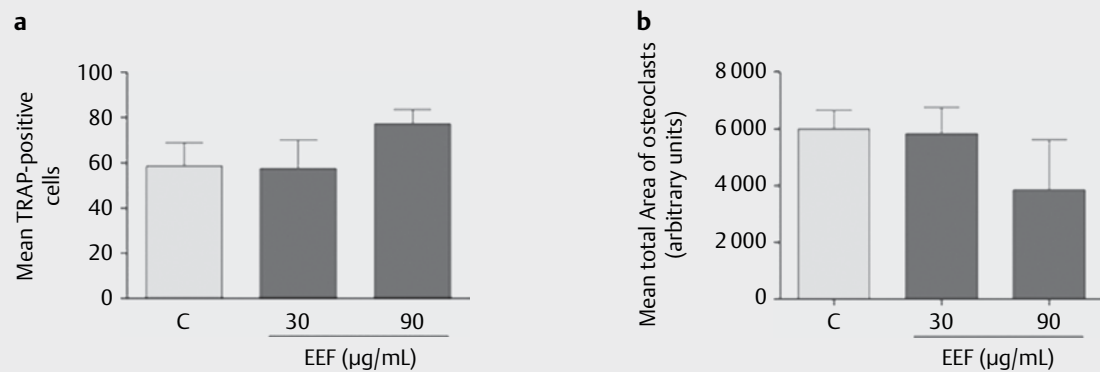

c

ethanolic extract $(\mu \mathrm{g} / \mathrm{mL})$

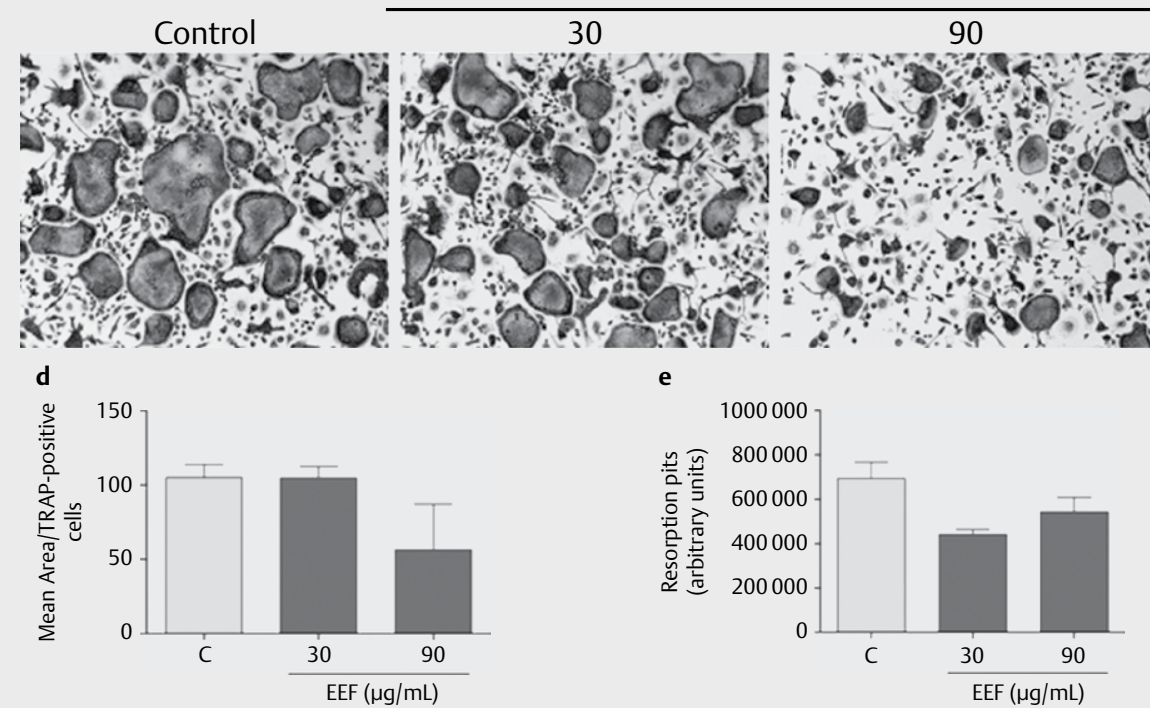

f ethanolic extract $(\mu \mathrm{g} / \mathrm{mL})$

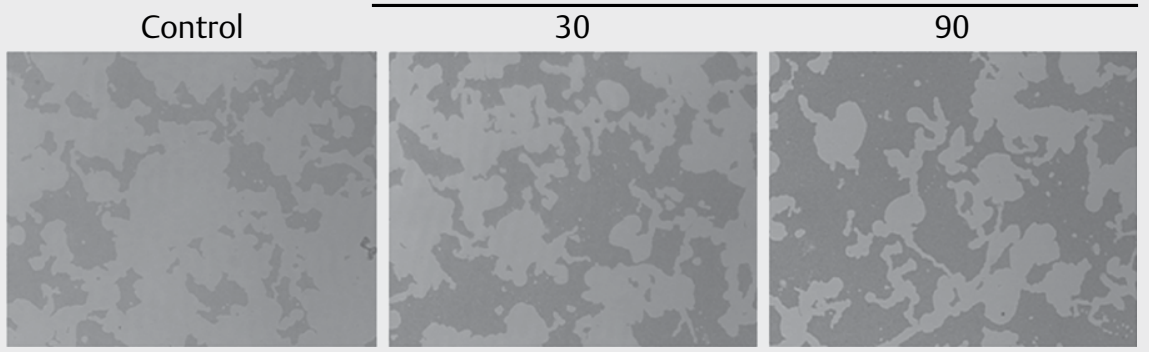

- Fig. 3 Effect of the ethanolic extract from H. speciosa fruits (EEF) on differentiation and activity of BMC-derived osteoclasts. a Number of TRAP positive cells. $\mathbf{b}$ Mean total area of TRAP positive cells. $\mathbf{c}$ Representative pictures of TRAP positive cells (20× magnification). $\mathbf{d}$ Mean area/TRAP positive cells. e Quantification of resorptive activity. $\mathbf{f}$ Representative images of resorption pits (20× magnification).

resorb it [24, 25]. Lately, a network of over 60 proteins has been associated with pathways regulating this process $[26,27]$. In this sense, each component of $H$. speciosa fruit that impacted the osteoclasts might have had different targets along the osteoclastogenesis pathway, and the inhibitory effects elicited by the EA might be a sum of each one of them. It should also be remembered that, in addition to bornesitol and quinic acid, several other compounds are present in the fraction. Hence, other components might be acting synergistically to cause inhibition of the resorption herein reported.

Taking the results of quinic acid and bornesitol in both cell cultures, it is feasible to suppose these cyclitols might interact syner- gistically, thus resulting in the broader spectrum of activity observed with EA. Actually, synergism has already been proposed to occur between other compounds from mangaba fruits [11].

The water fraction increased the mean number of TRAP + cells, but it did not increase either the mean area of those cells or the resorption pits ( $\triangleright$ Fig. 4S, Supporting Information). As similarly observed to RAW 264.7 cell culture, none of the substances showed an effect on cell viability/proliferation.

In conclusion, our study showed that components extracted from $H$. speciosa fruit had an impact on the cells responsible for bone resorption, making them promising tools for interference in pathological bone resorption. 

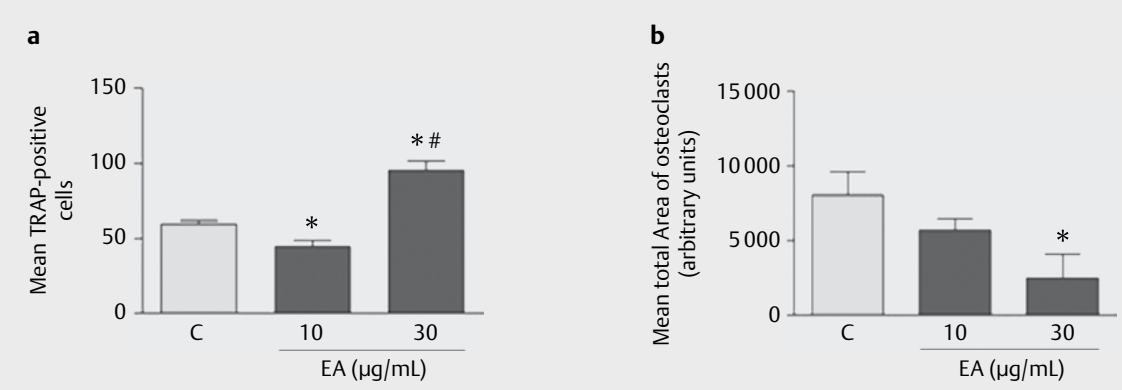

C
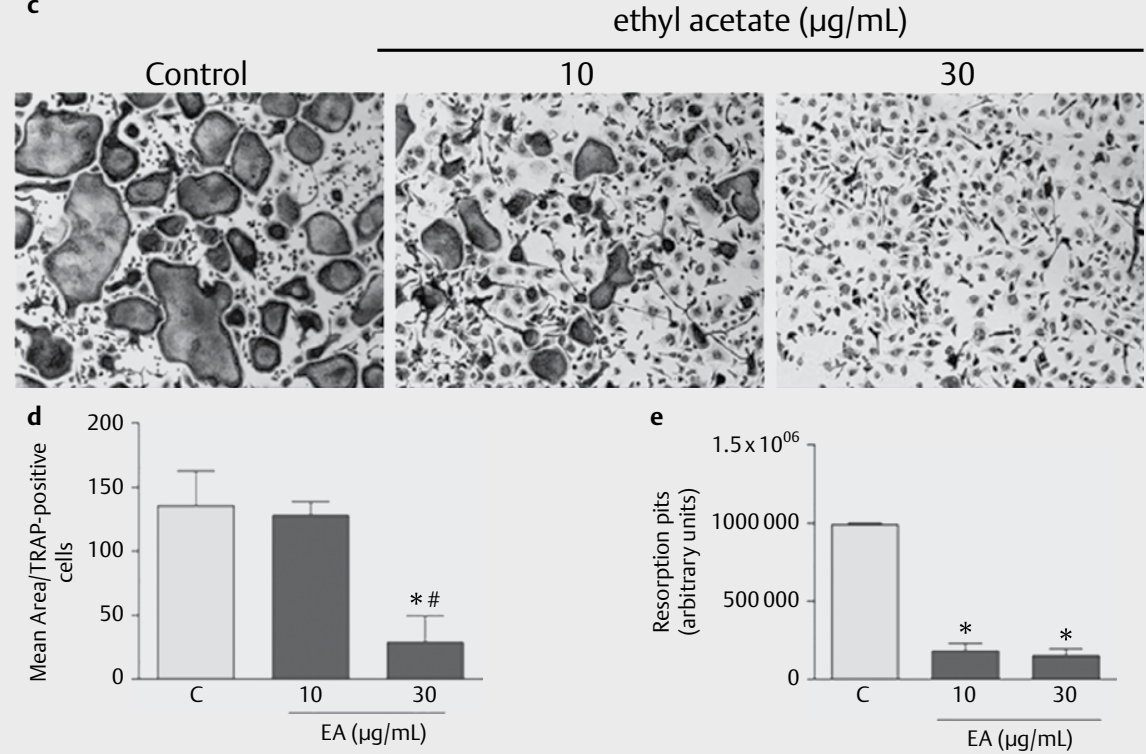

f

ethyl acetate $(\mu \mathrm{g} / \mathrm{mL})$

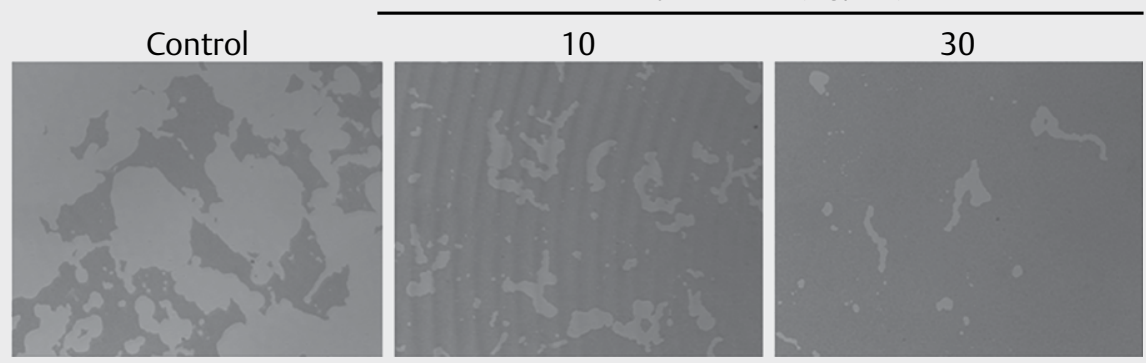

- Fig. 4 Effect of the ethanolic extract from $H$. speciosa fruits (EEF) on differentiation and activity of BMC-derived osteoclasts. a Number of TRAP positive cells. b Mean total area of TRAP positive cells. $\mathbf{c}$ Representative pictures of TRAP positive ( $20 \times$ magnification). $\mathbf{d}$ Mean area/TRAP positive cells. e Quantification of resorptive activity. $\mathbf{f}$ Representative images of resorption pits ( $20 \times$ magnification). ${ }^{*} \mathrm{P}<0.05$ compared with the control group; \#p<0.05 compared with EA $10 \mu \mathrm{g} / \mathrm{mL}$.

\section{Materials and Methods}

\section{Plant material, extract preparation, and fractionation}

The mature fruits of $H$. speciosa were collected in Brasilia de Minas, Minas Gerais state, Brazil. The plant species was identified by Dr. Maria das Dores Magalhães Veloso and a voucher specimen is deposited at the Herbarium Montes Claros (UNIMONTES), Brazil, under number 3816.

The selected fruits were sliced and dried in a ventilated oven at $40^{\circ} \mathrm{C}$ for 15 days. After drying, $50 \mathrm{~g}$ of the material was submitted to turbo-extraction with ethanol $96^{\circ} \mathrm{GL}$ for 2 min. The extract was filtered over paper and the residue was reextracted twice employing the same procedure. The extracts were combined and the solvent was removed in a rotatory evaporator under reduced pressure, at a maximal temperature of $50^{\circ} \mathrm{C}$, to afford $\operatorname{EEF}(9.14 \mathrm{~g})$.

EEF was submitted to fractionation by partition between immiscible solvents. A portion of it (1 g) was dissolved in $50 \mathrm{~mL}$ of water/ methanol (8:2) and sequentially partitioned with dichloromethane and $\mathrm{EA}(4 \times 40 \mathrm{~mL}$ each $)$. The solvents were removed under reduced pressure in a rotatory evaporator to give the dichloromethane (DCM $165.3 \mathrm{mg}$ ), EA (39.4 mg), and water (795.3 mg) fractions. 


\section{Analysis of the ethanol extract and ethyl acetate fraction by UPLC-ESI-MS}

The chemical composition of EEF and EA were investigated by UPLC coupled to mass spectrometry. Chromatographic separation was carried out on a Waters Acquity UPLC system (Waters) composed of a binary pump, autosampler, in-line degasser, and photodiode array detector (190-500 nm; Waters). The analyses were performed on an Acquity UPLC BEH C18 column-ethylene bridged hybrid octadecyl silane column $(2.1 \times 50 \mathrm{~mm}$ i.d., $1.7 \mu \mathrm{m}$; Waters $)$ at $40{ }^{\circ} \mathrm{C}$, eluting with a linear gradient of water $(\mathrm{A})$ and acetonitrile (B), both containing $0.1 \% \mathrm{v} / \mathrm{v}$ formic acid, at a flow rate of $0.3 \mathrm{~mL} /$ min, as follows: 5 to $95 \%$ of $B$ in $10 \mathrm{~min}$, and return to the initial conditions in $1 \mathrm{~min}$. A reequilibration time of 2 min was kept between runs. Spectroscopic conditions were employed as described previously by our research group [8].

MRM analyses were carried out on an Acquity UPLC BEH HILIC $(150 \times 2.1 \mathrm{~mm}, 1.7 \mu \mathrm{m}$; Waters $)$ in combination with a security guard column Acquity UPLC ${ }^{\circledR}$ BEH HILIC $(5 \times 2.1 \mathrm{~mm}, 1.7 \mu \mathrm{m}$; Waters $)$ at $20^{\circ} \mathrm{C}$. A linear gradient of water containing $0.1 \% \mathrm{v} / \mathrm{v}$ formic acid (A) and acetonitrile (B), at a flow rate of $0.3 \mathrm{~mL} / \mathrm{min}$, was employed: 0-5.25 min, 13\% B; 5.25-5.50 min, 75\% B; 5.50-9.00 min, 75\% B; 9.00-9.25, 13\% B; 9.25-15, $13 \%$ B.

A mass spectrometer Xeco Triple Quadrupole MS (Waters) equipped with an ESI source, operating in the negative ionization mode, was used in the analysis. The cone gas flow was set to $90 \mathrm{~L} / \mathrm{h}$ and desolvation gas flow to $900 \mathrm{~L} / \mathrm{h}$ at $450^{\circ} \mathrm{C}$. The capillary voltage was set to $3500 \mathrm{~V}$, cone gas voltage to $27 \mathrm{~V}$, and the source temperature was $120^{\circ} \mathrm{C}$. The data were accomplished in the multiple reaction mode using a specific transition (collision energy $14 \mathrm{~V}$ ), which corresponds to methanol lost.

Bornesitol (>98\% purity), employed as a reference compound for both the chemical analysis and biological assays, was previously isolated by our group [28], whereas quinic acid ( $>98 \%$ purity), chlorogenic acid ( > 95\% purity), and rutin trihydrate ( > 95\% purity) were purchased from Sigma-Aldrich.

\section{Mouse macrophage cell line RAW 264.7}

The murine monocyte/macrophage cell line RAW 264.7 was purchased from ATCC and grown in DMEM (Gibco) supplemented with $10 \% \mathrm{FBS}, 40$ units $/ \mathrm{mL}$ of penicillin, and $40 \mathrm{~g} / \mathrm{mL}$ of gentamicin. For osteoclast differentiation, RAW 264.7 cells were suspended in DMEM containing $10 \% \mathrm{FBS}$, seeded $\left(1 \times 10^{5}\right.$ cells/well) in 24 -well culture plates over $13 \mathrm{~mm}$ glass coverslips, and cultured with $50 \mathrm{ng} / \mathrm{mL}$ of soluble RANKL (PeproTech). Afterwards, cells were incubated with the following samples from $\mathrm{H}$. speciosa fruits: EEF (3, $10,30$, or $90 \mu \mathrm{g} / \mathrm{mL})$, $E A(3,10$, or $30 \mu \mathrm{g} / \mathrm{mL})$, water fraction $(3,10$, or $30 \mu \mathrm{g} / \mathrm{mL}$ ), quinic acid $(3,10$, or $30 \mu \mathrm{M})$, and bornesitol (3 or $10 \mu \mathrm{M}$ ), along with either PBS or DMSO ( $5 \%$ in PBS) as controls. For all cell cultures, PBS was used as the vehicle for the following constituents: EEF, quinic acid, and bornesitol; while DMSO was the vehicle for the water and EA. After $48 \mathrm{~h}$, a new stimulus with RANK-L $(50 \mathrm{ng} / \mathrm{mL})$ plus the isolated components was performed. The fresh medium containing DMEM plus $10 \%$ FBS with RANKL $(50 \mathrm{ng} / \mathrm{mL})$ was supplied at 2 day intervals. 7 days after the first stimulus, the cells were fixed and stained for TRAP (Sigma-Aldrich), following the manufacturer's instructions. TRAP positive multinucleated cells were captured under a light microscope $(40 \times$ magnification $)$ for further analysis.

\section{Bone marrow cell-derived osteoclasts}

Mouse BMCs were isolated from femurs and tibiae of C57BL6 mice and cultured with $\alpha$-MEM (Invitrogen), supplemented with $10 \%$ FBS, 100 units $/ \mathrm{mL}$ of penicillin, and $100 \mathrm{mg} / \mathrm{mL}$ of streptomycin. For osteoclast differentiation, cells were seeded with $10 \mathrm{~mL}$ of $\alpha$-MEM, containing $10 \%$ FBS with $30 \mathrm{ng} / \mathrm{mL}$ of M-CSF (R\&D Systems) and cultured for 3 days. The adherent cells (osteoclast precursors) were then plated in 96-well plates at a density of $2 \times 10^{4}$ cells/well and cultured in a medium containing M-CSF $(30 \mathrm{ng} / \mathrm{mL})$ and RANKL $(10 \mathrm{ng} / \mathrm{mL})$. Afterwards, cells were exposed to $\operatorname{EEF}(30$ or $90 \mu \mathrm{g} / \mathrm{mL}$ ), the water fraction ( 10 or $30 \mu \mathrm{g} / \mathrm{mL}$ ), EA (10 or $30 \mu \mathrm{g} / \mathrm{mL}$ ), quinic acid (3 or $10 \mu \mathrm{M})$, and bornesitol ( 3 or $10 \mu \mathrm{M})$, as well as to either PBS or DMSO as a control. Cells were incubated with each substance for $48 \mathrm{~h}$ when a new stimulation was performed for another $48 \mathrm{~h}$. Then, the cells were fixed, stained for TRAP (Sigma-Aldrich), and counted as described above.

The experiments were approved by the local Institutional Animal Ethics Committee (CEUA) under protocol number 84/2014.

\section{Cell viability assay}

The effect of the tested samples on cell viability/proliferation was evaluated in both cell cultures, after 7 days of incubation, using the MTT assay [29]. Spectrophotometric absorbance of each sample was then measured at $595 \mathrm{~nm}$.

\section{Osteoclast number and cell area}

Multinucleated ( 3 or more nuclei) TRAP + cells were considered osteoclasts [30] in both BMC and RAW 264.7 cell cultures. They were counted in the images captured from 9-10 nonconsecutive fields of each well of BMC-derived osteoclasts using Image J software (National Institutes of Health). RAW 264.7-derived TRAP + cells were counted in 9-10 nonconsecutive fields directly from the microscope view (40 × magnification, Olympus BX 51 TF) using a manual cell counter (VWR). Results are expressed as the average of TRAP + cells/well. Additionally, determination of the cell area in TRAP + cells was conducted in BMC-derived osteoclast images using Image J. The mean total cell area of each group is expressed as the total cell area divided by the total number of TRAP + cells per well.

\section{Pit formation assay}

For the pit resorption assay, BMC cells were plated on a Corning Osteo Assay Surface (Corning Life Sciences) in a 96-well plate, and treated with the samples in the same concentrations and conditions mentioned above. In order to observe the formation of the resorption pits, after 10 days of culture, cells were washed with PBS followed by treatment with $10 \%$ sodium hypochlorite for $5 \mathrm{~min}$ to remove the cells from the resorption plate. The wells were washed twice with distilled water and allowed to dry at room temperature overnight. The pits were observed and photographed under a microscope with $20 \times$ magnification. The pit areas were determined using contouring tools in Fiji software (National Institute of Health). The data are expressed as the mean of the total resorbed area for each study group in arbitrary units. 


\section{Statistics}

Each experiment was repeated at least twice using triplicates for each substance. Statistical significance was assessed by the software GraphPad Prism using one-factor analysis of variance (ANOVA) followed by the Student-Newman-Keuls test. Data are expressed as mean values \pm standard error of mean (SEM). Values of $p<0.05$ were considered statistically significant.

\section{Acknowledgments}

This work was supported by grants from CNPq and FAPEMIG.

\section{Conflict of Interest}

The authors declare no conflict of interest.

\section{References}

[1] Koch I, Rapini A, Simões AO, Kinoshita LS, Spina AP, Castello ACD. Apocynaceae. In: Lista de Espécies da Flora do Brasil. Jardim Botânico do Rio de Janeiro.Available at http://reflora.jbrj.gov.br/jabot/ floradobrasil/FB15558 Accessed March 2015;

[2] Clerici MTPS, Carvalho-Silva LB. Nutritional bioactive compounds and technological aspects of minor fruits grown in Brazil. Food Res Int 2011; 44: 1658-1670

[3] Bailão EFLC, Devilla IA, da Conceição EC, Borges LL. Bioactive compounds found in Brazilian Cerrado fruits. Int J Mol Sci 2015; 16: 23760-23783

[4] Hirschmann GS, Arias AR. A survey of medicinal plants of Minas Gerais, Brazil. J Ethnopharmacol 1990; 29: 159-172

[5] Ribeiro TP, Sousa TR, Arruda AS, Peixoto N, Gonçalves PJ, Almeida LM. Evaluation of cytotoxicity and genotoxicity of Hancornia speciosa latex in Allium cepa root model. Braz J Biol 2016; 76: 245-249

[6] Endringer DC, Valadares YM, Campana PRV, Guimarães KG, Pezzuto JM, Braga FC. Evaluation of Brazilian plants on cancer chemoprevention targets in vitro. Phytother Res 2010; 24: 928-933

[7] Silva GC, Braga FC, Lemos VS, Cortes SF. Potent antihypertensive effect of Hancornia speciosa leaves extract. Phytomedicine 2016; 23: 214-219

[8] Pereira AC, Pereira ABD, Moreira CCL, Botion LM, Lemos VS, Braga FC, Cortes SF. Hancornia speciosa Gomes (Apocynaceae) as a potential anti-diabetic drug. J Ethnopharmacol 2015; 161: 30-35

[9] Geller FC, Teixeira MR, Pereira AB, Dourado LP, Souza DG, Braga FC, Simões CM. Evaluation of the wound healing properties of Hancornia speciosa leaves. Phytother Res 2015; 29: 1887-1893

[10] Torres-Rêgo M, Furtado AA, Bitencourt MAO, Lima MC, Andrade RC, Azevedo EP, Soares Toda C, Tomaz JC, Lopes NP, da Silva-Júnior AA, Zucolotto SM, Fernandes-Pedrosa Mde F. Anti-inflammatory activity of aqueous extract and bioactive compounds identified from the fruits of Hancornia speciosa Gomes (Apocynaceae). BMC Complement Altern Med 2016; 16: 275-285

[11] Lima JP, Azevedo L, de Souza NJ, Nunes EE, Vilas Boas EVDB. First evaluation of the antimutagenic effect of mangaba fruit in vivo and its phenolic profile identification. Food Res Int 2015; 75: 216-224

[12] Teitelbaum SL. Bone resorption by osteoclasts. Science 2000; 289: 1504-1508

[13] Teitelbaum SL, Ross FP. Genetic regulation of osteoclast development and function. Nat Rev Genet 2003; 4: 638-649
[14] Buszewski B, Noga S. Hydrophilic interaction liquid chromatography (HILIC) - a powerful separation technique. Anal Bioanal Chem 2012; 402: $231-247$

[15] Gomes JHS, da Silva GC, Côrtes SF, de Pádua RM, Braga FC. Forced degradation of L-(+)-bornesitol, a bioactive marker of Hancornia speciosa: Development and validation of stability indicating UHPLC-MS method and effect of degraded products on ACE inhibition. J Chromatogr B Analyt Technol Biomed Life Sci 2018; 1093-1094 : 31-38

[16] Sittampalam GS, Coussens NP, Brimacombe K et al. editors. Assay Guidance Manual [Internet]. Bethesda, MD: Eli Lilly \& Company and the National Center for Advancing Translational Sciences; 2004

[17] Shim KS, Lee CJ, Yim NH, Ha H, Ma JY. A water extract of Malva verticillata seeds suppresses osteoclastogenesis and bone resorption stimulated by RANK ligand. BMC Complement Altern Med 2016; 16: 332-342

[18] Ha H, Shim KS, Kim T, An H, Lee C], Lee KJ, Ma JY. Water extract of Acer tegmentosum reduces bone destruction by inhibiting osteoclast differentiation and function. Molecules 2014; 19: 3940-3954

[19] Tang QY, Kukita T, Ushijima Y, Kukita A, Nagata K, Sandra F, Watanabe T, Toh K, Okuma Y, Kawasaki S, Rasubala L, Teramachi J, Miyamoto I, lijima T. Regulation of osteoclastogenesis by Simon extracts composed of caffeic acid and related compounds: successful suppression of bone destruction accompanied with adjuvant-induced arthritis in rats. Histochem Cell Biol 2006; 125: 215-225

[20] Rodan GA, Martin TJ. Therapeutic approaches to bone diseases. Science 2000; 289: 1508-1514

[21] Horcajada MN, Offord E. Naturally plant-derived compounds: Role in bone anabolism. Curr Mol Pharmacol 2012; 5: 205-218

[22] Neves JS, Franchin M, Rosalen PL, Omar NF, Dos Santos MA, Paschoal JAR, Novaes PD. Evaluation of osteogenic potencial of Hancornia speciosa latex in rat calvaria and its phytochemical profile. J Ethnopharmacol 2016; 183: 151-158

[23] Kaur G, Dufour JM. Cell lines: valuable tools or useless artifacts. Spermatogenesis 2012; 2: 1-5

[24] Teitelbaum SL. Osteoclasts: what do they do and how do they do it? Am J Pathol 2007; 170: 427-435

[25] Hsu H, Lacey DL, Dunstan CR. Tumor necrosis factor receptor family member RANK mediates osteoclast differentiation and activation induced by osteoprotegerin ligand. Proc Natl Acad Sci USA 1999; 96: 3540-3545

[26] Boyle W], Simonet WS, Lacey DL. Osteoclast differentiation and activation. Nature 2003; 423: 337-342

[27] Gingery A, Bradley EW, Pederson L, Ruan M, Horwood NJ, Oursler M]. TGF-beta coordinately activates TAK1/MEK/AKT/NFKB and SMAD pathways to promote osteoclast survival. Exp Cell Res 2008; 314 : 2725-2738

[28] Moraes TM, Rodrigues CM, Kushima H, Bauab TM, Villegas W, Pellizzon $\mathrm{CH}$, Brito AR, Hiruma-Lima CA. Hancornia speciosa: indications of gastroprotective, healing and anti-Helicobacter pylori actions. J Ethnopharmacol 2008; 120: 161-168

[29] Denizot F, Lang RJ. Rapid colorimetric assay for cell growth and survival. Modifications to the tetrazolium dye procedure giving improved sensitivity and reliability. J Immunol Methods 1986; 89: 271-277

[30] Woo JT, Nakagawa H, Notoya M, Yonezawa T, Udagawa N, Lee IS, Ohnishi M, Hagiwara H, Nagai K. Quercetin suppresses bone resorption by inhibiting the differentiation and activation of osteoclasts. Biol Pharm Bull 2004; 27: 504-509 